\title{
PERAN HUMAS DALAM PENGEMBANGAN PANTAI Pangandaran \\ SEBAGAI DESTINASI EKOWISATA MELALUI KEARIFAN LOKAL MASYARAKAT Pangandaran
}

\author{
Kokom Komariah dan Priyo Subekti \\ Universitas Padjadjaran
}

\begin{abstract}
ABSTRAK
Pangandaran merupakan pantai yang diproyeksikan untuk dijadikan tempat wisata nasional oleh pemerintah kabupaten Pangandaran. Penelitian ini bertujuan untuk mengetahui peran humas dalam pengembangan pantai Pangandaran sebagai ekowisata melalui kearifan lokal masyarakat Pangandaran. Metode yang digunakan adalah metode deskriptif dengan data kualitatif dan sample purposif. Hasil penelitian menunjukkan bahwa humas pemerintah berperan sebagai mediator dan fasilitator antara pemerintah dengan masyarakat dengan mengggunakan: komunikasi antarpersonal (menggunakan trik trik komunikasi secara psikologis); pendekatan Humas dengan komunikasi terbuka antara pemerintahan dengan masyarakat, dengan menggunakan opinion leader (tokoh masyarakat, tokoh agama dan tokoh keamanan); pendekatan media yaitu promosi melalui media massa terutama media cetak; melakukan hubungan baik dengan media (media relations) dengan wartawan dari berbagai media melalui sebuah kerja sama resmi melalui MoU. Humas Kabupaten Pangandaran memanfaatkan berbagai saluran komunikasi untuk mensosialisasikan program pemerintahnya terkait dengan pembentukan Pangandaran sebagai ekowisata dan sentral wisata pantai di Jawa Barat.
\end{abstract}

Kata-kata kunci: Peran humas, kearifan lokal, ekowisata, kawasan pantai, Pangandaran

\section{ROLE OF PUBLIC RELATIONS IN DEVELOPING COASTAL Pangandaran ECOTOURISM DESTINATION THROUGH Pangandaran COMMUNITY LOCAL WISDOM}

\begin{abstract}
Pangandaran is a beach that is projected to be a national tourist district government Pangandaran. This study aims to determine the role of public relations in Pangandaran beach as ecotourism development through local wisdom Pangandaran. The method used is descriptive method with qualitative data and purposive sample. The results showed that the government public relations role as mediator and facilitator between the government and communities to use traditional: interpersonal communication (communication using psychological tricks); PR approach with open communication between government by the people, using opinion leaders (community leaders, religious and security); approach, namely media campaign through the mass media, especially the print media; do a good relationship with the media (media relations) with journalists from various media through an official partnership through the MoU. District Public Relations Pangandaran utilize various communication channels to disseminate government programs associated with the formation of Pangandaran as ecotourism and tourism in central West Java. District Public Relations Pangandaran utilize various communication channels to disseminate government programs associated with the formation of Pangandaran as central of ecotourism and tourism in West Java.
\end{abstract}

Keywords: The role of public relations, local wisdom, ecotourism, beach area, Pangandaran

Korespondensi: Priyo Subekti, S. Sos., M. Si. Fakultas Ilmu Komunikasi Universitas Padjadjaran. Jl. Raya Bandung-Sumedang KM. 21 Jatinangor, 45363.Email: priyo. subekti@gmail.com 


\section{PENDAHULUAN}

Berbicara mengenai Kabupaten Pangandaran maka tidak terlepas dari Pantai Pangandaran yang merupakan potensi terbesar yang dimiliki Kabupaten Pangandaran selain dari wisata sungai (body rafting). Terdapat banyak objek wisata favorit baik oleh turis mancanegara maupun domestik. Objek wisata yang terdapat di Kabupaten Pangandaran yaitu: pantai Pangandaran, taman wisata alam (cagar alam pananjung), pantai batu hiu, pantai batu karas, pantai madasari, pantai karapyak, dan wisata sungai yaitu cukang taneuh (green canyon), citumang, santirah. Tersedia fasilitas hotel dengan kelas yang bervariasi dan cukup lengkap, restoran dan tempat hiburan lainnya (Pemkab Pangandaran: 2016)

Sebagian besar masyarakat Pangandaran bermata pencaharian sebagai nelayan dan wiraswasta menjadi pedagang di pesisir pantai Pangandaran. Dalam kehidupan kesehariannya terutama berkaitan dengan kehidupan nelayan yang tidak terlepas dari lingkungan pantai, Masyarakat Pangandaran sangat menghormati dan menjaga serta memelihara warisan budaya terutama yang berkaitan dengan lingkungan pantai, salah satunya yaitu budaya Hajat Laut. Hajat Laut merupakan warisan kearifan budaya lokal yang perlu untuk dijaga dan dilestarikan. Pangandaran juga memberikan wisata lainnya seperti tur ke pantai pasir putih, cagar alam dan diving untuk menikmati keindahan terumbu karang di kawasa pantai pasir putih.

Menurut Rahyono (2009: 7) kearifan lokal merupakan kecerdasan manusia yang dimiliki oleh kelompok etnis tertentu yang diperoleh melalui pengalaman masyarakat. Artinya, kearifan lokal yang dimiliki masyarakat Pangandaran adalah hasil dari pengalaman mereka sendiri dan belum tentu dialami oleh masyarakat yang lain. Nilai-nilai tersebut akan melekat sangat kuat pada masyarakat Pangandaran dan nilai itu sudah melalui perjalanan waktu yang panjang, sepanjang keberadaan masyarakat tersebut.

Pemerintahan Kabupaten Pangandaran sendiri sudah mulai menyadari potensi ekowisata dengan memanfaatkan kearifan lokal yang dimiliki oleh masyarakat Pangandaran misalnya wisata body rafting sungai Citumang, perjalanan wisata grand canyoon, cagar alam, menikmati keindahan pasir putih dan terumbu karang serta pesona wisata Hajat Laut yang diadakan setiap tahun. Kearifan lokal masyarakat Pangandaran disini adalah mereka mampu hidup harmoni bersama alam, dan justru mampu memanfaatkan lingkungan alam sebagai potensi wisata sekaligus melestarikan dan menjaga alam dari kerusakan.

Pemerintahan Pangandaran dalam hal ini humas pemerintah berperan sebagai mediator yang menjembatani kepentingan organisasi atau perusahaan dengan publiknya dalam hal ini pemerintahan dengan masyarakat pangandaran, sehingga berbagai aktivitas yang dilakukan senantiasa menciptakan, menjaga dan meningkatkan citra atau image yang positif.

Menurut Humas Pemerintah Kabupaten Pangandaran, Soni Agusman, saat ini pantai Pangandaran menjadi sentral tujuan dari semua daerah karena berperan sebagai kawasan wisata nasional. Maka karena itu peran humas menjadi sangat dominan dalam memberikan informasi terkait daerah wisata Pangandaran ke berbagai stakeholder melalui media massa ataupun media sosial.

Soni Agusman mengemukakan juga bahwa diharapkan pemerintah arif dan bijak dalam perancangan peraturan dearah terutama yang berkenaan dengan ekowisata, misalnya di Daerah Cimerak banyak potensi alam yang dapat digali. Jika potensi ini dapat tergali maka selain pemerintah, masyarakat setempat juga mendapatkan keuntungan dalam hal ekonomi.

Memberikan pelayanan kepada masyarakat merupakan tugas utama pemerintah. Pelayanan yang diberikan harus dilakukan sebaik mungkin sehingga tercipta hubungan yang harmonis antara pemerintah dengan masyarakat. Disinilah diperlukan peran humas pemerintah untuk mengembangkan kawasan pantai Pangandaran sebagai ekowisata melalui kearifan lokal masyarakat Pangandaran.

Fungsi paling dasar humas dalam pemerintahan adalah membantu menjabarkan dan mencapai tujuan program pemerintahan, meningkatkan sikap responsif pemerintah, serta memberi publik informasi yang cukup untuk dapat melakukan pengaturan diri sendiri (Lattimore dalam Lubis, 2012: 52). Dengan kata lain humas pemerintahan bertugas menjalankan kegiatan kebijakan 
dan pelayanan publik dengan memberikan berbagai informasi mengenai kebijakan dari pemerintahan yang mengikat masyarakat. Selanjutnya memberikan pelayanan publik yang terbaik, dengan birokrasi yang tidak berbelit-belit untuk memberikan kepuasan kepada rakyat atau masyarakat sehingga dunia pemerintahan memperoleh citra positif dari rakyat atau publik.

Selanjutnya peran yang dilaksanakan oleh Humas Kabupaten Pangandaran yang tercermin dalam aktivitasnya cenderung membentuk citra Pangandaran sebagai tempat wisata nasional. Aktivitas yang dilaksanakan oleh Humas Kabupaten Pangandaran seperti peliputan dan publikasi informasi terfokus pada kegiatan yang dilaksanakan oleh Bupati dan setiap jajaran pemerintahan Kabupaten Pangandaran.

Penyampaian informasi berupa program dan juga kebijakan Pemerintah Kabupaten Pangandaran menggunakan media berupa pidato yang dibacakan oleh Bupati, media luar ruang berupa baliho, dan website. Humas juga menjalin hubungan dan kerja sama dengan beberapa media massa, baik media massa nasional maupun lokal. Hal ini dilakukan untuk mempermudah wartawan meliput mengenai kegiatan-kegiatan Pemerintah Kabupaten Pangandaran terutama kegiatan yang dilaksanakan Bupati.

Ekowisata berbeda dengan wisata alam. Wisata alam, merupakan setiap jenis wisatawisata massal, wisata pertualangan, ekowisata yang memanfaatkan sumber daya alam dalam bentuk yang masih lain dan alami, termasuk spesies, habitat, bentangan alam, pemandangan dan kehidupan air laut dan air tawar. Dengan kata lain wisata alam adalah perjalanan wisata yang bertujuan untuk menikmati kehidupan liar atau daerah alami yang belum dikembangkan. Pengertian wisata alam adalah kegiatan perjalanan yang dilakukan oleh seseorang atau kelompok dengan mengunjungi tempat tertentu untuk tujuan rekreasi, pengembangan pribadi, atau mempelajari daya tarik alam dengan memanfaatkan potensi sumberdaya alam, baik itu alami maupun budidaya (Sekretariat Kabinet Republik Indonesia: 2016).

Ekowisata merupakan kegiatan wisata yang menaruh perhatian besar terhadap kelestarian sumber daya pariwisata. Berdasarkan
Damanik dkk. (2006) selanjutnya disebutkan ada tiga perspektif ekowisata yaitu, Ekowisata sebagai produk yaitu semua atraksi yang berbasis pada sumber daya alam, Ekowisata sebagai pasar yaitu perjalanan diarahkan pada upaya-upaya pelestarian lingkungan, Ekowisata sebagaipendekatan pengembangan yaitumetode pemanfaatan dan juga pengelolaan sumberdaya pariwisata secara ramah lingkungan.

Ekowisata merupakan suatu bentuk wisata yang sangat erat hubungannya dengan prinsip konservasi. Menurut pemikiran Millar (Iwan Nugroho, 2011: 121), ditemukan empat isu konservasi yang berkaitan dengan ekowisata: 1) Kegiatan wisata yang cenderung berkarakter massal (mass Tourism). Karakteristik industri pariwisata umumnya menghasilkan pengaruh yang signifikan dan massal. 2) Objek wisata yang spesifik. Industri pariwisata umumnya memiliki sarana akomodasi yang terstandardisasi dengan kenyamanan tertentu, misalnya fasilitas parkir, toilet atau kamar hotel. 3) Pemberdayaan penduduk lokal. Sekalipun orientasi utama ekowisata adalah konservasi, namun insentif ekonomi harus mangalir khususnya pada penduduk lokal. 4) Penelitian dan pengembangan. Faktor-faktor yang tidak terhitung (intangible) di dalam sumber daya alam masih belum banyak teridentifikasi. Ekowisata merupakan jenis pariwisata yang menekankan pada pentingnya konservasi.

Ekowisata merupakan salah satu usaha yang memprioritaskan berbagai produk-produk pariwisata berdasarkan sumber daya alam, pengelolaan ekowisata untuk meminimalkan dampak terhadap lingkungan hidup, pendidikan yang berasaskan lingkungan hidup, sumbangan kepada upaya konservasi dan meningkatkan kesejahteraan untuk masyarakat lokal (World Tourism Organization, 2002) dalam Fahriansyah dan Yoswaty (2012: 347).

Kriteria Pengetahuan Tradisional (PT) terkait Perlindungan dan Pengelolaan Lingkungan Hidup (Alexander dan Ayu, 2011), secara garis besar, adalah: (1) Dihasilkan, direpresentasikan, dikembangkan, dilestarikan, dan ditransmisikan dalam konteks tradisional dan antar generasional, (2) Secara nyata dapat dibedakan, atau diakui menurut kebiasaan, sebagai berasal dari suatu komunitas masyarakat hukum adat, yang melestarikan dan mentransmisikan Pengetahuan Tradisional 
(PT) tersebut dari generasi ke generasi, dan terus menggunakan dan mengembangkannya dalam konteks tradisional di dalam komunitas itu sendiri, (3) Merupakan bagian integral dari indentitas budaya suatu masyarakat hukum adat, yang dikenal dan diakui sebagai pemegang hak atas Pengetahuan Tradisional (PT) itu melalui aktivitas pemangkuan, penjagaan, pemilikan kolektif, maupun tanggung-jawab budaya. Kaitan antara Pengetahuan Tradisional (PT) dan pemangkunya ini dapat diungkapkan, baik secara formal atau informal, melalui praktek-praktek kebiasaan atau praktek-praktek tradisional, protokol, atau hukum nasional yang berlaku, (4) Diwariskan dari generasi ke generasi, meski pun pemakaiannya mungkin tidak terbatas lagi di dalam komunitas terkait saja.

Kearifan lokal menurut Undang Undang No. 32 tahun 2009 tentang Perlindungan dan Pengelolaan Lingkungan Hidup BAB I Pasal 1 butir 30 adalah "nilai-nilai luhur yang berlaku dalam tata kehidupan masyarakat untuk antara lain melindungi dan mengelola lingkungan hidup secara lestari".

Ardhana menjelaskan bahwa menurut perspektif kultural, kearifan lokal adalah berbagai nilai yang diciptakan, dikembangkan dan dipertahankan oleh masyarakat yang menjadi pedoman hidup mereka. Termasuk berbagai mekanisme dan cara untuk bersikap, bertingkah laku dan bertindak yang dituangkan sebagai suatu tatanan sosial. (dalam Apriyanto, 2008: 4)

Selanjutnya Ridwan memaparkan bahwa kearifan lokal atau sering disebut local wisdom dapat dipahami sebagai usaha manusia dengan menggunakan akal budinya (kognisi) untuk bertindak dan bersikap terhadap sesuatu, objek, atau peristiwa yang terjadi dalam ruang tertentu (2007: 2).

Adapun menurut Keraf(2010: 369) bahwa kearifan lokal adalah sebagai berikut: yang dimaksud dengan kearifan tradisional di sini adalah semua bentuk pengetahuan, keyakinan, pemahaman atau wawasan serta adat kebiasaan atau etika yang menuntun perilaku manusia dalam kehidupan di dalam komunitas ekologis. Jadi kearifan lokal ini bukan hanya menyangkut pengetahuan dan pemahaman masyarakat adat tentang manusia dan bagaimana relasi yang baik di antara manusia, melainkan juga menyangkut pengetahuan, pemahaman dan adat kebiasaan tentang manusia, alam dan bagaimana relasi di antara semua penghuni komunitas ekologis ini harus dibangun. Seluruh kearifan tradisional ini dihayati, dipraktikkan, diajarkan dan diwariskan dari satu generasi ke generasi lain yang sekaligus membentuk pola perilaku manusia sehari-hari, baik terhadap sesama manusia maupun terhadap alam dan Yang Gaib.

Menurut Cutlip dan Center dalam Effendy (2009: 116) PR adalah fungsi manajemen yang menilai sikap publik, mengidentifikasi kebijaksanaan dan tata cara seseorang atau organisasi demi kepentingan publik, serta merencanakan dan melakukan suatu program kegiatan untuk meraih pengertian dan dukungan publik.

Peran Public Relations diperlukan untuk menyusun dan mengevaluasi strategi strategi pemasaran maupun sosialisasi yang efisien dan berorientasi pada tujuan organisasi. Berdasarkan uraian tersebut maka dapat dikatakan bahwa keberadaan Public Relations dalam suatu perusahaan atau lembaga mempunyai posisi sangat penting untuk menjaga kestabilan suatu organisasi dan memiliki mutu yang baik (Putri, 2015: 121).

PR juga membantu organisasi untuk mengantisipasi dan merespons persepsi dan opini, merespons nilai dan gaya hidup yang baru, merespons pergeseran di antara direktorat dan di dalam lembaga legislatif, dan merespons perubahan-perubahan lain yang terjadi dalam lingkungan karena tanpa PR yang efektif, organisasi akan cenderung menjadi tidak peka terhadap perubahan yang terjadi di sekitarnya dan menjadi tidak peduli dengan lingkungannya (Cutlip, Center, dan Broom, 2006: 29). Jadi dapat dikatakan bahwa Public Relations merupakan fungsi manajemen tertentu yang membantu membangun dan menjaga lini komunikasi, pemahaman bersama, penerimaan mutual dan kerja sama antara organisasi atau perusahaan dengan publiknya.

Peranan Humas pemerintah adalah untuk memberikan sanggahan mengenai pemberitaan yang salah dan merugikan pemerintah, serta mengkomunikasikan atau menginformasikan berbagai kebijakan pemerintah kepada masyarakat. Hal ini bertujuan untuk membentuk citra positif pemerintah daerah tersebut di mata publiknya. Pentingnya peran Humas instansi 
dan lembaga perintah dalam masyarakat modern yaitu dalam melakukan kegiatankegiatan dan operasinya di berbagai tempat berbagai bidang. Teknik yang digunakan dalam humas di perintah tidak ada bedanya dengan teknik yang digunakan humas di bidang lain yaitu penyampaian informasi dan komunikasi (Moore, dalam Lubis 2012: 52). Dalam hal ini humas kabupaten Pangandaran bekerja sama dengan wartawan untuk melakukan press release dan jumpa press mengenai informasi berbagai kegiatan dan aktifitas yang dilakukan pemerintahan Kabupaten Pangandaran.

Humas dibentuk di lembaga pemerintah diantaranya berfungsi sebagai juru bicara pemerintah, melakukan hubungan timbal balik antara pemerintah daerah dengan masyarakat umum dan organisasi kemasyarakatan untuk memperjelas kebijakan dan kegiatan pemerintah daerah, melakukan hubungan intern dengan satuan dan unit kerja di lingkungan pemerintah, melaksanakan usaha untuk peningkatan peliputan kegiatankegiatan yang dilaksanakan oleh pemerintah maupun masyarakat dan melaksanakan koordinasi/kerja sama dengan organisasi kewartawanan. Dengan pelaksanaan peran humas pemerintah, tujuan akhirnya adalah untuk membentu citra yang positif tentang pemerintah di mata masyarakatnya (Moore, dalam Lubis 2012: 53).

\section{METODE PENELITIAN}

Metode yang digunakan dalam penelitian ini adalah metode deskriptif, yaitu penelitian yang memaparkan situasi atau peristiwa atau penelitian observasional seperti yang dikemukakan oleh Wood (dalam Rakhmat, 2004: 25). Lebih jauh Rahmat mengemukakan bahwa penelitian deskriptif ditujukan untuk: (1) mengumpulkan informasi aktual secara rinci yang melukiskan gejala yang ada, mengidentifikasikan masalah atau memeriksa kondisi dan praktek-praktek yang berlaku, (3) membuat perbandingan atau evaluasi, (4) menentukan apa yang dilakukan orang lain dalam menghadapi masalah yang sama dan belajar dari pengalaman mereka untuk menetapkan rencana dan keputusan pada waktu yang akan datang (Rakhmat, 2004: 25)

Narasumber dalam penelitian ini adalah 1) kepala Humas Pemerintahan Kabupaten
Pangandaran; 2) Kasubag Keprotokoleran; 3) Kasubag Sandi \& Telekomunikasi 4) Kabid Perdagangan dan Perindustian. Sample yang digunakan adalah sample purposif. Pengumpulandatamenggunakan: 1)wawancara mendalam; Wawancara men-dalam atau disebut juga wawancara tidak terstruktur dilakukan dengan pertanyaan yang bersifat "open-ended" dan mengarah pada kedalaman informasi, dilakukan dengan cara yang tidak formal, dan bisa dilakukan secara berulang pada informan yang sama. Kelonggaran dan kelenturan cara ini akan mampu menggali kejujuran informan untuk memberikan informasi yang sebenarnya, terutama yang berkaitan dengan latar belakang informan yang diteliti. Teknik wawancara ini akan dilakukan pada semua informan, 2) studi pustaka; Studi pustaka akan dilakukan terhadap tulisan dan pemberitaan di media massa dan literatur terkait dengan budaya populer dan bentuk perlawanan terhadap populer yang relevan dengan penelitian ini, 3) Dokumentasi; dokumentasi dilakukan dengan tujuan merekam kondisi lingkungan pantai Pangandaran, kantor humas, informan dan kegiatan kegiatan kemasyarakatan. Hal ini dilakukan untuk mendapatkan gambaran umum mengenai objek dan subjek penelitian.

\section{HASIL DAN PEMBAHASAN}

Peran Humas Dalam Pengembangan Pantai Pangandaran Sebagai Ekowisata Melalui Kearifan Lokal Masyarakat Pangandaran

Humas Pemerintah harus mampu menjadi jembatan antara pemerintah itu sendiri dengan publiknya tanpa menyembunyikan informasi. Dengan keterbukaan informasi di bagian Humas Pemerintah akan membentuk opini publik terhadap kinerja pemerintahan untuk dapat dinilai dan dianggap baik atau buruk terhadap capaian kinerjanya. Dengan adanya opini publik tersebut akan mempengaruhi tingkat kepercayaan publik terhadap instansi pemerintahan. Kabag Humas Kabupaten Pangandaran sendiri mengartikan bahwa tugas utama sebagai seorang Humas Pemerintah ialah membranding pemkab itu sendiri agar lebih baik dipandangan warga negaranya. Kemudian beliau mengatakan bahwa humas itu bukan hanya sebagai pemadam kebakaran saja, di mana ia bertindak hanya ada masalah, melainkan harus dapat terlibat langsung secara 
manajerial dan fungsional.

Humas merupakan fungsi manajemen dalam sebuah organsiasi yang berperan untuk membangun kesepahaman antara organisasi dan publiknya (Berg, dalam Lubis, 2012: 57). Berdasarkan peran yang dimilikinya, humas sebenarnya lebih merupakan aktivitas mengelola arus pesan/komunikasi yang terjadi di institusinya. Manakala pesan itu dapat menjadi lifeblood di institusinya, maka upaya untuk membangun understanding, goodwill dan image (citra) dengan para stakeholdernya serta merta akan mudah dicapai (Sinatra, 2008).

Pranata Humas merupakan jabatan fungsional yang keberadaannya diatur dalam Keppres nomor 87 tahun 1999, "jabatan fungsional adalah kedudukan yang menunjukkan tugas, tanggungjawab, wewenang dan hak Pegawai Negeri Sipil(PNS) dalam satuan tugas organisasi yang dalam melaksanakan tugasnya didasarkan pada keahlian atau keterampilan tertentu serta mandiri". Pranata humas sebagai salah satu jabatan fungsional PNS yang diberi tugas, tanggung jawab, wewenang dan hak secara penuh oleh pejabat yang berwenang untuk melakukan kegiatan pelayanan informasi dan kehumasan, baik informasi berskala nasional maupun daerah/lokal.

Keberadaan Pranata Humas sangat di butuhkan oleh setiap instansi pemerintahan atau. Selain memiliki peran penting dalam mendukung tugas pemerintahan, Humas Pemerintahan secara eksplisit diatur dalam Peraturan Menteri Negara Pendayagunaan Aparatur Negara Nomor. 109/M. PAN/11/2005. Pasal 4 dikatakan: Tugas pokok pranata humas adalah melakukan kegiatan pelayanan informasi dan kehumasan, meliputi perencanaan pelayanan informasi dan kehumasan, pelayanan informasi, hubungan kelembagaan, hubungan personil, dan pengembangan pelayanan informasi dan kehumasan.

Secara garis besar Kepala Humas Kabupaten Pangandaran menginginkan Kabupaten Pangandaran menjadi tempat wisata dunia (internasional yang mencakup wisata alam, budaya dan wisata buatan) dengan cara: (1) Menggunakan komunikasi antarpersonal (menggunakan trik-trik komunikasi secara psikologis); artinya humas dan stafnya melakukan pendekatan secara personal dengan menggunakan kedekatan secara emosial kepada masyarakat. Cara ini meng-gunakan metode hearing yaitu dengan mendatangi tokoh tokoh masyarakat informal dan non formal kemudian mendengarkan masukan dan respons dari mereka terhadap program yang sudah dijalankan oleh pemerintah. Jika ada saran dan masukan dari masyarakat akan di tampung dan kemudian akan dijadikan sebagai bahan rekomendasi untuk program selanjutnya, (2) Pendekatan Humas dengan komunikasi terbuka antara pemerintahan dengan masyarakat, dengan menggunakan opinion leader (tokoh masyarakat, tokoh agama dan tokoh keamanan); metode ini humas memanfaatkan jaringannya dengan para tokoh masyarakat baik tokoh sosial, agama dan budaya dalam mensosialisasikan program-program dari pemerintahan kabupaten Pangandaran, (3) Menggunakan pendekatan media yaitu promosi melalui media massa terutama media cetak; Humas memanfaatkan beberapa media cetak baik lokal dan nasional untuk mendiseminasikan infromasi mengenai kondisi Pangandaran, kegiatan-kegiatan yang dilakukan oleh pemerinatahan kabupaten Pangandaran dan kebijakan-kebijakan yang akan diberlakukan. Selain menggunakan media cetak, humas juga memanfaatkan radio di Pangandaran yaitu radio komunitas Pangandaran. Bagi masyarakat Pangandaran rakom menjadi penting dalam kaitannya sebagai hak untuk mengatahui dan memberitahukan informasi sebagai perwujudan hak asasi manusia dalam bidang informasi. The rights to know dan the rights to inform. Tidak hanya itu, dengan biaya operasional dan harga perangkat yang relatif murah masyarakat tidak membutuhkan pemodal besar ataupun pemerintah sehingga media informasinya relatif bebas kepentingan. Penggunaan rakom adalah suatu piranti komunikasi yang baru dan merupakan sesuatu yang potensial dalam mensukseskan pembangunan desa-kota dan merupakan sebuah strategi untuk membantu warga menempatkan komunitas pada posisi yang lebih baik dalam menerapkan proyek pembangunan, membantu mata penca-hariannya dan memberdayakan warga untuk memperbaiki kehidupannya, memberikan dasar kepada komunitas untuk berdiskusi dan membicarakan strategi pembangunan juga pemerintah lokal untuk menginformasikan kepada warga mengenai program-program baru dalam konteks lokal, (4) Melakukan hubungan baik dengan 
media (media relations) dengan wartawan dari berbagai media melalui sebuah kerja sama resmi melalui MoU; Media Relations merupakan salah satu kegiatan humas yang berhubungan dengan media massa dalam hal publikasi dan press release di media massa mengenai aktivitas dan kegiatan yang dilakukan oleh pemerintah Kabupaten Pangandaran. Dalam kegiatan media relations, hubungan baik yang terbangun antara humas dengan media massa bukanlah tujuan utama meskipun itu penting. Tujuan utama dari kegiatan media relations ini adalah terciptanya kepercayaan dalam diri masyarakat (stakeholder) terhadap lembaga dalam hal ini adalah pemrinatah Kabupaten Pangandaran.

Senada dengan yang dikemukakan Jefkins dalam (Partao, 2005: 8) yaitu: Media Relations atau press relations (hubungan pers) adalah usaha untuk mencapai publikasi atau penyiaran yang maksimum atas suatu pesan atau informasi PR dalam rangka menciptakan pengetahuan dan pemahaman bagi khalayak dari perusahaan yang bersangkutan. Menurut Jefkins lebih lanjut, tujuan pokok diadakannya hubungan pers adalah menciptakan penge-tahuan dan pemahaman, bukan semata-mata untuk menye-barkan suatu pesan sesuai keinginan perusahaan induk atau klien demi mendapatkan suatu citra atau sosok yang lebih indah dari pada aslinya di mata umum.

Menurut definisi dari Scott M. Cutlip dan Allen H. Center (2006), humas merupakan fungsi manajemen yang menilai sikap publik, mengidentifikasi kebijakan dan tata cara seseorang atau organisasi demi kepentingan publik, serta merencanakan dan melakukan suatu program kegiatan untuk memperoleh pengertian, pemahaman, dan dukungan dari publiknya.

MenteriKomunikasidanInformatikaRudiantara pada acara Forum Tematik Kehumasan yang bertema "Penguatan Kelembagaan Humas PemerintahPusat dan Daerah UntukMendukung Fungsi Government Public Relations" (GPR), pada 5 Maret 2015, di Aula Sekretariat Negara, mengingatkan kalangan humas harus mengubah pola pendekatan kepada masyarakat, yakni dari cara kuno ke modern yang lebih partisifatif. Selain itu, humas harus mengajak masyarakat menjadi bagian dari proses sehingga ada jalinan emosional dengan humas, dan masyarakat pun akan merasa memiliki tanggungjawab dan melakukan sharing kepedulian yang lebih banyak lagi (Pemkab, 2016).

Para praktisi humas mengungkapkan bahwa dunia public relations sedang memasuki masa kebangkitan dengan keberadaan teknologi informasi dan komunikasi. Keberadaannya membuat para praktisi humas mampu mencapai sasarannya kepada publik secara langsung tanpa intervensi pihak-pihak yang dapat menghambat kegiatan komunikasinya.

Selain itu, teknologi komunikasi yang dapat digunakan dalam public relations adalah Internet dan telepon. Internet bukan hanya sarana untuk mencari informasi, melainkan sarana yang baik untuk berkomunikasi. Misal, dengan e-mail, media sosial, website, semua kegiatan komunikasi dan hubungan dapat berjalan dengan lancar. Jadi dengan teknologi komunikasi, kemampuan untuk menyampaikan dan menerima pesan, jauh lebih mudah dan efektif.

Humas Kabupaten Pangandaran memanfaatkan berbagai saluran komunikasi untuk mensosialisasikan program pemerintahnya terkait dengan pembentukan Pangandaran sebagai ekowisata dan sentral wisata pantai di Jawa Barat. Dari hasil wawancara penulis mengidentifikasikan beberapa cara pengkomunikaian yang dilakukan Humas Pangandaran.

Menggunakan media cetak yaitu Pikiran Rakyat, Kabar Tasikmalaya, Koran Sindo dan Pangandaran News. Humas pemerintah harus mampu bersinergi/bermitra dengan wartawan (Media Cetak, Media Elektronik dan Media Sosial), serta lembaga pers lainnya dalam membantu pemerintah untuk menyebarluaskan informasi program pembangunan kepada masyarakat. Kepala Humas Pangandaran mengemukakan bahwa media sosialisasi yang paling efektif di Pangandaran adalah surat kabar yaitu Pikiran Rakyat, Kabar Tasikmalaya, Koran Sindo, Pangandaran News.

Sinergitas atau hubungan kemitraan antara Humas dan Wartawan dapat berjalan dengan baik dan tujuan dapat diwujudkan secara optimal, maka ada beberapa hal yang sangat penting dilaksanakan oleh setiap pejabat humas, di antaranya: (1) Hubungan Humas dengan Wartawan bersifat professional; profesional dalam hal ini adalah pejabat humas mengesampingkan kepentingan pribadi dan 
memperlakukan wartawan sesuai dengan hak dan kewajibannya selaku insan pers. Hal ini penting untukmenghindari wartawan tanpa surat kabar atau wartawan nakal, (2) Humas harus mengetahui seluk beluk wartawan, termasuk irama kerjanya wartawan serta fungsi media massa; humas senantiasa berhubungan dengan wartawankarena itu humas diharapkan mengerti bagaimana sistem kerja seorang wartawan, (3) Humas harus memiliki kemampuan praktik jurnalisme seperti meliput wawancara, memotret, menulis berita langsung, berita khas (feature) dan artikel. Selain itu, humas dapat mengenali wartawan dan jajaran redaksi secara pribadi. Serta humas tidak boleh diskriminatif terhadap wartawan/media massa tertentu, namun harus diperlakukan secara adil.

Beberapa metode yang dilakukan oleh humas dalam melakukan sosialisasi mengenai kebijakan pemerintah kabupaten Pangandaraan yang berkenaan dengan ekowisata dan kearifan lokal yaitu: (1) Menggunakan saluran saluran komunikasi yang ada di masyarakat seperti: PKK, Kelompok tani, aparat desa dan saluran komunikasi lainnya. (2) Saluran komunikasi atau forum komunikasi tersebut dapat dimanfaatkan oleh humas menjadi sarana masyarakat untuk menyam-paikan aspirasi maupun hanya sekedar berbagi permasalahan yang ada. Selain itu juga forum ini dijadikan sebagai salah satu agenda untuk menyampaikan berbagai informasi dari pemerintah yang harus disampaikan kepada setiap masyarakat desa. Apalagi jika kegiatan tersebut tetap sudah terjadwal akan memudahkan humas untuk mengatur waktu dan agenda dalam rangka mengadakan pertemuan dengan warga terkait dengan pemebrian informasi dan hearing. (3) Menggunakan kearifan lokal setempat yaitu mengadakan Taraweh Keliling (Tarling) memanfaatkan momen Ramadhan untuk mensosialisasikan kegiatan dan program pemerintah. Dengan memanfaatkan momen tarawih yang notabene warga paling banyak berkumpul untuk melaksanakan ibadah tarawih maka pihak humas dapat memberikan informasi berupa peraturan, bantuan, kegiatan, dan lain sebagainya. Informasi ini kemudian dapat disebarkan oleh warga yang ikut taraweh kepada warga lainnya. (4) Selain tarling, pemerintah juga menggunakan momen pagelaran Senin Badud dan mengadakan perlombaan kuliner makanan 'kampung'.
Saat ini peran humas di lembaga pemerintahan tidak bisa dipandang sebelah mata karena dengan tuntutan reformasi termasuk reformasi dibidang birokrasi, pemerintah wajib menyelenggarakan aktivitasnya dengan memenuhi kriteria asas-asas pemerintahan yang baik. "Transparancy" menjadi salah satu ukuran dari suatu penyelenggaraan pemerintahan. Masyarakat berhak mengetahui informasi apapun dari pembuat dan pelaku kebijakan.

Dalam melaksanakan perannya Humas Kabupaten Pangandaran melakukan komunikasi dua arah. Humas menyampaikan kebijakan dan program menggunakan saluran komunikasi berupa media massa, baik media luar ruang berupa baliho dan poster, pidato dan presentasi pimpinan, website, publikasi khusus maupun dengan hubungan dengan media massa lainnya. Humas juga melakukan upaya komunikasi untuk mendapatkan respons dari masyarakat terhadap Pemerintah kabupaten Pangandaran kadangkala melaksanakan evaluasi kerja berdasarkan beritaberita dan umpan balik yang terdapat pada media massa, dan pertemuan-pertemuan informal kemudian hasil evaluasi tersebut disampaikan kepada pimpinan yang menjadi umpan balik terhadap kebijakan dan program yang telah dikeluarkan Pemerintah kabupaten Pangandaran.

Humas dibentuk di lembaga pemerintah diantaranya sebagai juru bicara pemerintah, melakukan hubungan timbal balik antara pemerintah daerah dengan masyarakat umum dan organisasi kemasyarakatan untuk memperjelas kebijakan dan kegiatan pemerintah daerah, melakukan hubungan intern dengan satuan dan unit kerja di lingkungan pemerintah, melaksanakan usaha untuk peningkatan peliputan kegiatan-kegiatan yang dilaksanakan oleh pemerintah maupun masyarakat dan melaksanakan koordinasi/kerja sama dengan organisasi kewartawanan (Moore, dalam Lubis 2012: 53). Dengan pelaksanaan peran humas pemerintah, tujuan akhirnya adalah untuk membentuk citra yang positif tentang pemerintah di mata masyarakatnya.

Humas di pemerintah Kabupaten Pangandaran dengan demikian dapat disimpulkan menjadi pemberi informasi kepada masyarakat sekaligus penghubung antara pemerintah dan masyarakat. Hal ini bisa dipahami karena pemerintah adalah agen dari masyarakat itu sendiri. Masyarakat memberikan haknya untuk diwakilkan 
kepada orang-orang pemerintahan agar bisa diselenggarakan dengan sebaik-baiknya. Maka suatu kewajaran apabila pemerintah harus tetap terhubung dengan masyarakat dan setiap aspeknya menyentuh langsung kehidupan masyarakat. Humas menjadi palang pintu bagi hubungan yang harmonis antara pemerintah dengan publik atau masyarakat.

Hambatan atau kendala yang dihadapi oleh humas kabupaten Pangandaran dalam mengkomunikasikan strategi pengembangan kawasan Pangandaran menjadi ekowisata berdasarkan kearfian lokal setempat.

Belum ada pemahaman yang memadai mengenai komunikasi dalam organisasi serta pengelolaan kehumasan pemerintah yang optimal dan profesional. Sebagian besar humas pemerintah dalam pelaksanaan tugas dan fungsinya masih banyak terkendala adanya tata kerja, infrastruktur kehumasan, organisasi humas, kultur/budaya kerja atau pejabat, sarana dan prasaranayang memadai.Akibat darikendala tersebut membuat lemahnya pengelolaan "early warning system" terhadap isu dan krisis, saluran komunikasi belum terbuka, dan belum ada mekanisme untuk mengukur efektivitas saluran komunikasi yang ada.

Humas dalam upaya membangun citra pemerintah di mata masyarakat maupun dunia, yang semestinya merupakan ujung tombak dari suatu lembaga pemerintahan yang dapat menjembatani arus informasi dari pemerintah kepada masyarakat atau sebaliknya pada era saat ini. Selain itu, UU No. 28 Tahun 1999 tentang Penyelenggaraan Negara yang Bersih dan Korupsi, Kolusi, dan Nepotisme (KKN) mengamanatkan agar aparatur negara mampu menjalankan tugas dan fungsinya secara profesional, produktif, transparan dan bebas KKN. Perwujudan nyatanya antara lain tercermin dari penyelenggaraan pelayanan publik.

Hal ini juga merupakan dari salah satu bagian dari pelaksanaan reformasi birokrasi dalam fungsi komunikasi dalam organisasi. Fungsi tersebut telah diatur dalam Peraturan Menteri Negara Pendayagunaan Aparatur Negara Nomor PER/12/M. PAN/08/2007 tentang Pedoman Umum Hubungan Masyarakat di Lingkungan Instansi Pemerintah, serta Kesepakatan Bersama Menteri Dalam Negeri, Menteri Komunikasi dan Informatika, dan
Menteri Negara Pendayagunaan Aparatur Negara tentang Revitalisasi Fungsi Hubungan Masyarakat pada Instansi Pemerintah, Kesekretariatan Lembaga Negara, Pemerintah Daerah, dan Badan Usaha Milik Negara/Daerah. Ditambah lagi dengan telah disahkannya UU Nomor 14 Tahun 2008 tentang KIP.

Untuk menyikapi hal itu, maka diperlukan peningkatan dan pedoman umum dari penyelenggaraann humas pemerintah terhadap peningkatan pelayanan publik, terutama sebagai solusi terhadap permasalahan fungsi komunikasi dalam organisasi baik internal maupun eksternal. Pedoman umum ini sebagai prinsip dan panduan bagi setiap instansi pemerintah dipusat dan daerah dalam pengelolaan komunikasi organisasi di instansi pemerintah. Humas pada era sekarang sudah harus berubah atau perlu di reformasi, dari Humas yang reaktif menjadi Humas yang proaktif.

Humas Pemerintahan pada dasarnya tidak bersifat politis. Bagian humas di pemerintahan dibentuk untuk mempublikasikan atau mempromosikan kebijakan-kebijakan mereka. Memberi informasi secara teratur tentang kebijakan, rencana-rencana, serta hasil-hasil kerja institusi serta memberi pengertian kepada masyarakat tentang peraturan dan segala sesuatunya yang berpengaruh terhadap kehidupan masyarakat. Selain keluar humas pemerintahan dan politik juga harus memungkinkan untuk memberi masukan dam saran bagi para pejabat tentang segala informasi yang diperlukan dan reaksi atau kemungkinan reaksi masyarakat akan kebijakan institusi, baik yang sedang dilaksanakan, akan dilaksanakan ataupun yang sedang diusulkan.

Tugas pemerintah memang sangat berat, sebab masyarakat yang dihadapi terdiri dari berbagai publik dengan kepentingan yang sangat kompleks pula. Hal ini memang tidak lepas pula dari "karakteristik" yang melekat dalam setiap program pemerintah antara lain: (1) Program pemerintah ditujukan untuk masyarakat luas. Dengan berbagai latar belakang, karakter, ekonomi, pendidikan yang beragam, (2) Sering kali hasilnya abstrak,yang sulit dilihat dalam waktu dekat bahkan panjang sekalipun karena sifatnya yang integral dan berkesinambungan, (3) Program pemerintah selalu mendapat pengawasasn dari berbagai kalangan, terutama pers, LSM dan sebagainya. Mereka sangat 
berperan dalam proses penyadaran masyarakat mengenai permasalahan mereka.

Karakteristik itulah yang dapat dijadikan latar belakang mengapa humas pemerintahan perlu diterapkan dan dikembangkan secara professional. Namun tugas yang berat tersebut ternyata masih ditambah dengan hambatan penerapan humas yang ideal di pemerintahan.

Dari hasil wawancara dengan kepala Humas Pangandaran maka dapat disimpulkan bahwa kendala yang dihadapi oleh mereka meliputi: (1) Masalah jaringan. Penyebarluasan informasi salah satunya melalui jaringan Internet. Tidak semua daerah di Pangandaran tercover oleh jaringan yang dapat mengakses Internet. Selain masalah infrastukur pendukung Internet, juga masalah sumber daya manusia yang mampu dan terampil menggunakan serta mampu memonitoring sistem masih kurang, apalagi jumlah tenaga teknis yang mengerti jaringan Internet masih terbatas, (2) Karakteristik masyarakat yang berbeda secara sosial ekonomi dan tingkat pendidikan yang menjadikan tingkat penerimaan informasi menjadi berbeda beda. Dalam hal ini humas pemerintahan Pangandaran dapat mencari solusi lain dengan mencari metode sosialisasi yang tepat yang dapat dipahami oleh masyarakat berbagai tingkat pendidikan yang berbeda. Humas dapat menggunakan media massa cetak, radio, atau media luar ruang dengan bahasa yang disesuaikan dengan tingkat rata rata pendidikan masyarakat Pangandaran secara umum. (3) Masih adanya kepercayaan mengenai hal hal yang gaib di masyarakat terhadap tempat di Pangandaran yang dianggap wingit sehingga tidak diperbolehkan untuk dijadikan tempat wisata umum. Masyarakat Pangandaran masih kuat dalam memegang mitos atau kepercayaan dari nenek moyang, tetapi dengan pemebrian informasi dan pemahaman secara kontinyu, masyarakat dapat menerima program-program yang diusulkan oleh pemerintah kabupaten Pangandaran. Humas Pangandaran menggunakan para tokoh agama dan tokoh yang di tuakan untuk mendekati masyarakat dalam hal kepercayaan nenek moyang, (4) Sumber daya manusia di bagian Humas Pangandaran masih terbatas dalam hal pengetahuan dan kemampuan mengenai kehumasan. Untuk meningkatkan kemampuan mereka di bidang humas di perlukan pelatihan atau bimbingan teknis mengani kehumasan.

Segala sesuatu yang menghalangi kelancaran komunikasi disebut sebagai gangguan (noise). Kata noise dipinjam dari istilah ilmu kelistrikan yang mengartikan noise sebagai keadaan terentu dalam sistem kelistrikan yang mengakibatkan tidak lancarnya atau berkurangnya ketepatan peraturan. Pencetakan huruf yang saling bertindihan dalam suatu surat kabar atau majalah akan menjadi gangguan bagi pembacanya. Kata-kata yang diucapkan secara tidak tepat akan mengganggu komunikasi dengan masyarakat. Apabila kata-kata atau kalimat yang disampaikan tidak atau bukan merupakan kata-kata yang secara luas dipahami oleh masyarakat. Penggunaan kata-kata asing yang sulit dimengerti tentu merupakan bagian dari noise atau gangguan yang harus dihindari oleh humas (Nurdianti, 2014: 148).

Di samping itu, ada pula gangguan yang berasal dari saluran komunikasi tersebut, misalnya interferensi yang terjadi pada gelombang radio yang mengakibatkan tidak jelasnya isi siaran diterima oleh pendengar. Namun demikian, pada hakikatnya kebanyakan dari ganguan yang timbul, bukan berasal dari sumber atau salurannya, tetapi dari audience (penerima)nya. Manusia sebagai komunikan memiliki kecendrungan untuk acuh tak acuh, meremehkan sesuatu, salah menafsirkan, atau tidak mampu mengingat dengan jelas apa yang diterimanya dari komunikator. Setidak-tidaknya ada tiga faktor psikologis yang mendasari hal itu (Suprapto, 2009: 14), yaitu: (1) Selective attention. Orang biasanya cenderung untuk mengekspos dirinya hanya kepada hal-hal (komunikasi) yang dikehendakinya. Misalnya, seseorang tidak berminat membeli mobil, jelas dia tidak akan berminat membaca iklan jual beli mobil, (2) Selective perception. Suatu kali, seseorang berhadapan dengan suatu peristiwa komu-nikasi, maka ia cenderung menafsirkan isi komunikasi sesuai dengan prakonsepsi yang sudah dimiliki sebelumnya. Hal ini erat kaitannya dengan kecenderungan berpikir secara stereotip, (3) Selective retention. Meskipun seseorang memahami suatu komunikasi, tetapi orang berkecenderungan hanya mengingat apa yang mereka ingin untuk diingat. Misalnya, setelah membaca suatu artikel berimbang mengenai komunisme, seorang mahasiswa yang 
anti komunis hanya akan mengingat hal-hal jelek mengenai komunisme. Sebaliknya mahasiswa yang prokomunis cenderung untuk mengingat kelebihan-kelebihan sistem komunisme yang diungkapkan oleh artikel tersebut.

\section{SIMPULAN}

Cukup banyak hambatan atau kendala yang dihadapi humas kabupaten Pangandaran dalam mengkomunikasikan strategi pengembangan kawasan Pangandaran menjadi ekowisata berdasarkan kearifan lokal setempat, diantaranya: Humas Kabupaten Pangandaran berperan sebagai menjadi pemberi informasi kepada masyarakat sekaligus penghubung antara pemerintah dan masyarakat. Masalah SDM humas yang masih minim pengetahuan dan keterampilan di bidangnya. Masalah teknis yaitu jaringan komunikasi. Penyebarluasan informasi salah satunya melalui jaringan Internet. Tidak semua daerah di Pangandaran tercover oleh jaringan yang dapat mengakses Internet. Karakteristik masyarakat yang berbeda secara sosial ekonomi dan tingkat pendidikan yang menjadikan tingkat penerimaan informasi menjadi berbeda beda. Dan masih percaya kepadahal hal yang gaib atau mitos di masyarakat terhadap tempat di Pangandaran yang di anggap wingit sehingga tidak diperbolehkan untuk dijadikan tempat wisata umum.

Sebaiknya dilakukan pelatihan kehumasan untuk meningkatkan pengetahuan dan kemampuan sumber daya manusia di lingkungan Humas Kabupaten Pangandaran. Selain menggunakan website, sebaiknya dseminasi informasi mengenai kebijakan pemerintah dan aktivitas pemerintah disebarkan melalui media cetak dan media luar ruang, karena tidak semua daerah dapat mengakses Internet. Humas Kabupaten Pangandaran perlu dipikirkan bentuk dan jenis diseminasi infromasi yang berbeda kepada masyarakat karena tingkat pendidikan masyarakat Pangandaran juga bervariasi.

Humas Kabupaten Pangandaran perlu meli-batkan tokoh tokoh sosial, ekonomi dan agama dalam berbagai program kegiatan yang akan dilakukan oleh pemerintahan kabupaten Pangandaran. Selain mengggunakan media Internet dan media massa, Humas kabupaten Pangandaran dapat memanfaatkan saluran komunikasi dan forum komunikasi yang ada di masyarakat Pangandaran misalnya taraweh keliling, pengajian, perlombaan dan arisan.

\section{DAFTAR PUSTAKA}

Apriyanto, Y. dkk. (2008). Kearifan lokal dalam mewujudkan pengelolaan sumber daya air yang berkelanjutan. Bogor: Makalah Pada PKM IPB.

Ardianto, E. \& Soemirat, S. (2009). Dasardasar public relations. Bandung: Rosdakarya.

Budhyana, I. (2008). Kebijakan disbudpar dalammengembangkankawasan wisata di Jawa Barat. Makalah pada Seminar Pembangunan Kepariwisataan di Jawa Barat. Bandung: UPI

Cutlip, S. M. , Center, A. H, \& Broom, G. M. (2006). Effective Public Relations. Edisi 8. Jakarta: Indeks Kelompok Gramedia

Dahuri, R et al. (2001). Pengelolaan sumber daya wilayah pesisir dan lautan secara terpadu. Jakarta: Pradnya Paramita.

Damanik, J. \& Weber, H. (2006). Perencanaan ekowisata dari teori ke aplikasi. Yogyakarta: PUSPAR UGM dan Andi

David, F. R. (2006). Manajemen strategis. Jakarta: Salemba Empat

Dinas Kebudayaan dan Pariwisata Kabupaten Ciamis. Rencana Strategi (Renstra) Disbudpar Kabupaten Ciamis tahun 2009-2014. Ciamis

Effendy, O. U. (2009). Human relations \& public relations. Bandung: Mandar Maju

Fahriansyah \& Yoswaty, D. (2012). Pembangunan ekowisata di kecamatan tanjung balai asahan, sumatera utara: faktor ekologis hutan mangrove. Jurnal Ilmu dan Teknologi Kelautan Tropis, Vol. 4, No. 2, Hlm. 346-359, Desember 2012

Fandeli, C. (2000). Pengertian dan konsep dasar ekowisata. Yogyakarta: Fakultas Kehutanan Univ. Gadjah Mada. 
Kanal Pengetahuan. (2016). Pengertian wisata alam. Diakses dari http: //www. kanal. web. id/2015/08/pengertianwisata-alam. html

Keraf, A. S. (2010). Etika lingkungan hidup. Jakarta: Penerbit Buku Kompas

Lubis, E. E. (2012). Peran humas dalam membentuk citra pemerintah. Jurnal Ilmu Administrasi Negara, Volume 12, Nomor 1, Juli 2012: 1 - 73

Nugroho,I.(2011).EkowisatadanPembangunan Berkelanjutan. Yogyakarta: Pustaka Pelajar.

Nurdianti, S. R. (2014). Analisis faktor-faktor hambatan komunikasidalam sosialisasi program keluarga berencana pada masyarakat kebon agungsamarinda. eJournal Ilmu Komunikasi, Volume 2, Nomor 2, 2014: 145-159

Partao, Z. A. (2005). Optimalisasi fungsi media relations untuk keberhasilan komunikasi krisis. Jurnal Komunikologi Vol. 2 No. 1, Maret 2005

Pemkab. Pangandaran. (2016). Profil Pangandaran. Diakses dari http: // www. Pangandarankab. go. id/profilPangandaran
Putri, I. D. A. H. (2015). Peranan public relations dalam menjaring pemasang iklan pada radio republik indonesia cabang madya-denpasar. Jurnal Kajian Komunikasi, Volume 3, No. 2, Desember 2015 hlm 120-132

Rahyono, FX. (2009). Kearifan budaya dalam kata. Jakarta: Wedatama Widaya Sastra

Rakhmat, J. (2004). Metode penelitian komunikasi. Bandung: Remaja Rosdakarya.

Ridwan, N. A. (2007). Landasan keilmuan kearifan lokal. Jurnal Studi Islam dan Budaya. Vol. 5, (1), 27-38.

Sekretariat Kabinet Republik Indonesia. (2015). Peran humas dalam mensukseskan program pemerintah. Diakses dari http: //setkab. go. id/ peran-humas-dalam-mensukseskanprogram-pemerintah

Sinatra,L.\&Darmastuti, R.(2008).Kajianperan public relations dalam meningkatkan citra perguruan tinggi swasta di jawa tengah. Jurnal SCRIPTURA, 2 (2).

Suprapto, T. (2009). Pengantar teori dan manajemen komunikasi. Yogyakarta: MedPress (anggota IKAPI) 